\title{
Relationship between chemokines and T lymphocytes in the context of respiratory allergies (Review)
}

\author{
NICOLAE OVIDIU BERGHI ${ }^{1}$, MIHAI DUMITRU ${ }^{2}$, DANIELA VRINCEANU ${ }^{3}$, \\ RADU CONSTANTIN CIULUVICA ${ }^{2}$, ANCA SIMIONIUC-PETRESCU ${ }^{3}$, RAMONA CARAGHEORGHEOPOL $^{4}$, \\ CATALIN TUCUREANU ${ }^{4}$, ROXANA SFRENT CORNATEANU ${ }^{5}$ and CALIN GIURCANEANU ${ }^{1}$
}

${ }^{1}$ Department of Oncologic Dermatology, 'Elias' Emergency University Hospital, 'Carol Davila' University of Medicine and Pharmacy, 011461 Bucharest; ${ }^{2}$ Anatomy Department, 'Carol Davila' University of Medicine and Pharmacy, 050474 Bucharest;

${ }^{3}$ ENT Department, 'Carol Davila' University of Medicine and Pharmacy, 010271 Bucharest;

${ }^{4}$ Immunology Laboratory, 'Cantacuzino' National Military-Medical Institute for Research and Development, 050096 Bucharest; ${ }^{5}$ Department of Physiopathology and Immunology, 'Carol Davila' University of Medicine and Pharmacy, 041914 Bucharest, Romania

Received May 22, 2020; Accepted June 22, 2020

DOI: $10.3892 / \mathrm{etm} .2020 .8961$

\begin{abstract}
Allergic diseases have been classified in the last decades using various theories. The main classes of the newest classification in allergic respiratory diseases focus on the characterization of the endotype (which takes into account biomarkers related to determinant pathophysiological mechanisms) and of the phenotype (based on the description of the disease). Th2, Th1 and Th17 lymphocytes and the type of inflammatory response mediated by them represent the basis for Th2 and non-Th2 endotype classification. In addition, new lymphocytes were also used to characterize allergic diseases: Th9 lymphocytes, Th22 lymphocytes, $\mathrm{T}$ follicular helper cells $\left(\mathrm{T}_{\mathrm{FH}}\right)$ lymphocytes and invariant natural killer T (iNKT) lymphocytes. In the last decade, a growing body of evidence focused on chemokines, chemoattractant cytokines, which seems to have an important contribution to the pathogenesis of this pathology. This review presents the interactions between chemokines and $\mathrm{Th}$ lymphocytes in the context of Th2/non-Th2 endotype classification of respiratory allergies.
\end{abstract}

Correspondence to: Professor Mihai Dumitru, Anatomy Department, 'Carol Davila' University of Medicine and Pharmacy, Bloc 33, 1 Sarandy Frosa, 050474 Bucharest, Romania

E-mail: orldumitrumihai@yahoo.com

Abbreviations: UAD, united airway disease; CC, chemokine; CK, cytokine; AHR, airway hyperreactivity; AR, allergic rhinitis; DC, dendritic cell

Key words: endotypes, chemokines, lymphocytes, respiratory allergies, rhinitis, asthma

\section{Contents}

1. Introduction

2. Th2 endotype

3. Non-Th2 endotype

4. Lymphocyte diversity, plasticity and heterogeneity

5. Chemokines

6. Conclusions

\section{Introduction}

Over the years, there has been an important number of attempts to classify allergic diseases, especially on respiratory level. Respiratory allergies may begin at any level of the respiratory tract (nose, sinuses, lungs) and, over time, they can generalize throughout, process known as the United Airway Disease (UAD) (1). One of them was based on the evaluation of specific mechanisms that represent the pathophysiological background of the disease: endotypes (2). A disease endotype includes the specific biological pathway (describing an etiology and/or a firm pathophysiologic mechanism) that explains the observable properties of a phenotype (clinical description of a disease without a connection with underlying pathology). Lötvall et al (2) were the first to propose the criteria that characterizes an endotype. In order to be accepted, an endotype description should take into account at least 5 of these 7 aspects: Clinical, biomarkers, lung function, genetics, histopathology, epidemiology and treatment response (3). At the moment, there are two main endotypes described: Th2 and non-Th2.

\section{Th2 endotype}

Over the last decade, one of the most studied endotypes was the one based on type 2 immune response. Historically, allergic asthma and rhinitis were hypothesized to be produced by this type of mechanism $(4,5)$. Type 2 immune 
response is based on the contribution of the following cells: Th2 cells (6), type 2 B cells (7), interleukin-4 (IL-4) secreting NK cells (8), IL-4 secreting T-NK cells (9), mast cells, eosinophils, basophils, their cytokines (CK) (5): IL-4, IL-5, IL-9, IL-13, along with those CKs secreted by tissue cells (5): IL-25 (10), IL-31 (11), IL-33 (12) and TSLP (13). Starting from the characterization of Th2 endotype, experts identified two endotypes: Th2-high and Th2-low (14), which were divided further in several sub-endotypes: IL-5-high, IL-13-high, IgE-high (5). This kind of endotype may also be characterized by several other biomarkers: blood or sputum eosinophilia (15), periostin (16), considered to be characteristic for it. Type 2 immune response underlines atopic asthma and allergic rhinitis (AR) as fundamental for the united airway concept (5). In addition, type 2 immune response seems to be important in chronic rhinosinusitis (CRS) with nasal polyposis (CRSwNP), tissue eosinophilia and evidence of eosinophil activation, being closely associated with remodeling features of CRS (5). The whole disease spectrum of atopic dermatitis (AD) from background inflammation in asymptomatic patients to chronic disease is also covered by this type of mechanism (5).

\section{Non-Th2 endotype}

Recent years brought to the allergist's attention a new endotype in allergic respiratory diseases: non-type 2 immune response driven endotype. This endotype is related to neutrophilic inflammation, Th17 activation (17), neurogenic inflammation and tissue remodeling (4). There are two major mechanisms that are considered to contribute to definition of this endotype: the activation of the IL-17-dependent pathway and neutrophil intrinsic abnormalities (4). It was demonstrated that IL-17 is linked to remodeling (18), airway hyper-reactivity (AHR) (19), asthma severity (20) and inflammation (21). Lung airway neutrophilia seems to be associated with lower lung function, thickening airway walls and more air trapping (3). For decades, Th1 immune response was considered the main mechanism responsible for the pathophysiology of non-atopic asthma (5). This response is characterized by the domination of Th1 cells and their mediators: interferon- $\gamma(\operatorname{IFN}-\gamma)(22)$ and tumor necrosis factor- $\alpha$ (TNF- $\alpha$ ) (23). Initially described in non-atopic asthma or in severe asthma, it has recently been connected with allergic rhinitis and asthma as well $(24,25)$. TNF- $\alpha$ produces a nasal inflammatory response in patients with AR characterized by plasma exudation and late phase neutrophil activity $24 \mathrm{~h}$ post nasal challenge (24). An increase of IFN- $\gamma$ levels was observed due to increased exposure to polycyclic aromatic hydrocarbons (PAHs), known for their predisposition to atopy (25). In recent years, mixed endotypes/sub-endotypes, such as Th1/Th17 (4) or Th2/Th17 endotype were proposed (26).

\section{Lymphocyte diversity, plasticity and heterogeneity}

Besides the classic difference Th1 vs. Th2, immunology has been described previously in many other types of lymphocytes. The importance of Th17 in respiratory allergies has been presented before. Th9 cells have an important role in the immune responses regulation. They express predominantly IL-9. IL-9 causes the induction of lung eosinophilia, increased serum total IgE levels, airway hyperreactivity (27), the generation of cytokines from active mast cells; it also up-regulates high-affinity IgE receptors on mast cells (28). Th22 cells are positive for chemokine receptors CCR4, CCR6 and CCR10 and produce mostly IL-22. IL-22 has been found to be increased in patients with AR (29) and asthma (30). GM-CSF producing T cells were also described. Increased levels of GM-CSF were found during the birch-pollen season in the nasal lavage (31). $\mathrm{T}$ follicular helper cells $\left(\mathrm{T}_{\mathrm{FH}}\right)$ represent a specialized CXCR5-expressing $\mathrm{CD}^{+} \mathrm{T}$ cell population, regulated by Bcl-6. Peripheral circulating $\mathrm{T}_{\mathrm{FH}}$ can be divided into three subsets: $\mathrm{cT}_{\mathrm{FH}}$ cells (BCL6-CXCR3 ${ }^{+} \mathrm{CCR}^{-}$), $\mathrm{cT}_{\mathrm{FH} 2}$ cells (BCL6-CXCR3-CCR6-), and $\mathrm{CT}_{\mathrm{FH} 17}\left(\mathrm{BCL}^{-} \mathrm{CXCR}^{-} \mathrm{CCR}^{+}\right)$cells, based on the differential expression of the chemokine receptors CXCR3 and CCL6 (32). Significant levels were found in child and adult asthma patients (33). In addition, $\mathrm{T}_{\mathrm{FH}}$ were positively correlated with total IgE levels in the blood (34). Unconventional $\mathrm{T}$ lymphocytes, such as invariant natural killer T (iNKT) and mucosal-associated invariant T cells (MAIT), are considered potential candidates for studying the mechanisms underlying the pathophysiology of asthma (35). MAIT cells produce low-to-moderate levels of IL-4 and IL-13 (36). A recent study suggests that MAIT-17 cells may be associated with asthma symptoms (37).

Another important aspect is represented by the plasticity of $\mathrm{T}$ cells. Previously it was shown that $\mathrm{T}$ lymphocytes can display an important grade of plasticity when they are exposed to re-polarizing signals (38). Signaling via Toll-like receptors can drive Th2 cells to an IFN- $\gamma$-secreting phenotype (39). Th9 cells may develop from Th2 cells under the action of TGF- $\beta$ (40). Th1/Th2 hybrid cells may develop from Th2 precursor cells under the influence of interferons (41). Th1 and Th17 cells may produce IL-4 under some circumstances (42).

\section{Chemokines}

Chemokines (CC) are chemoattractant cytokines that signal through seven-transmembrane-spanning domain, pertussis toxin-sensitive, G-protein-coupled receptors (GPCRs). They are classified into four families, based on the arrangement of the first two $\mathrm{N}$-terminal cysteine residues within their amino acid sequence: $\mathrm{CXC}(\alpha)$ family, $\mathrm{CC}(\beta)$ family, $\mathrm{CX} 3 \mathrm{C}(\delta)$ family and $\mathrm{C}(\gamma)$ family. Chemokines can be divided functionally into inflammatory and homeostatic. Inflammatory chemokines are produced during an inflammatory response by activated leukocytes or tissue resident cells. Examples include CXCL9 [monokine induced by $\gamma$-interferon (MIG)], CXCL10 [interferon- $\gamma$-induced protein 10 (IP-10)] and CXCL11 (interferon-inducible $\mathrm{T}$ cell $\alpha$-chemoattractant (ITAC)] that attract Th1 cells and neutrophil-attracting chemokines: CXCL1 [growth-regulated oncogene (GRO $\alpha)$ ] and CXCL8 (interleukin-8). Homeostatic chemokines are produced by healthy tissues and direct leukocytes to fulfill their normal roles, which are immune surveillance, hematopoiesis and embryogenesis: CCL19 [EBI1 ligand chemokine (ELC)], CCL21 [secondary lymphoid-tissue chemokine (SLC)], 


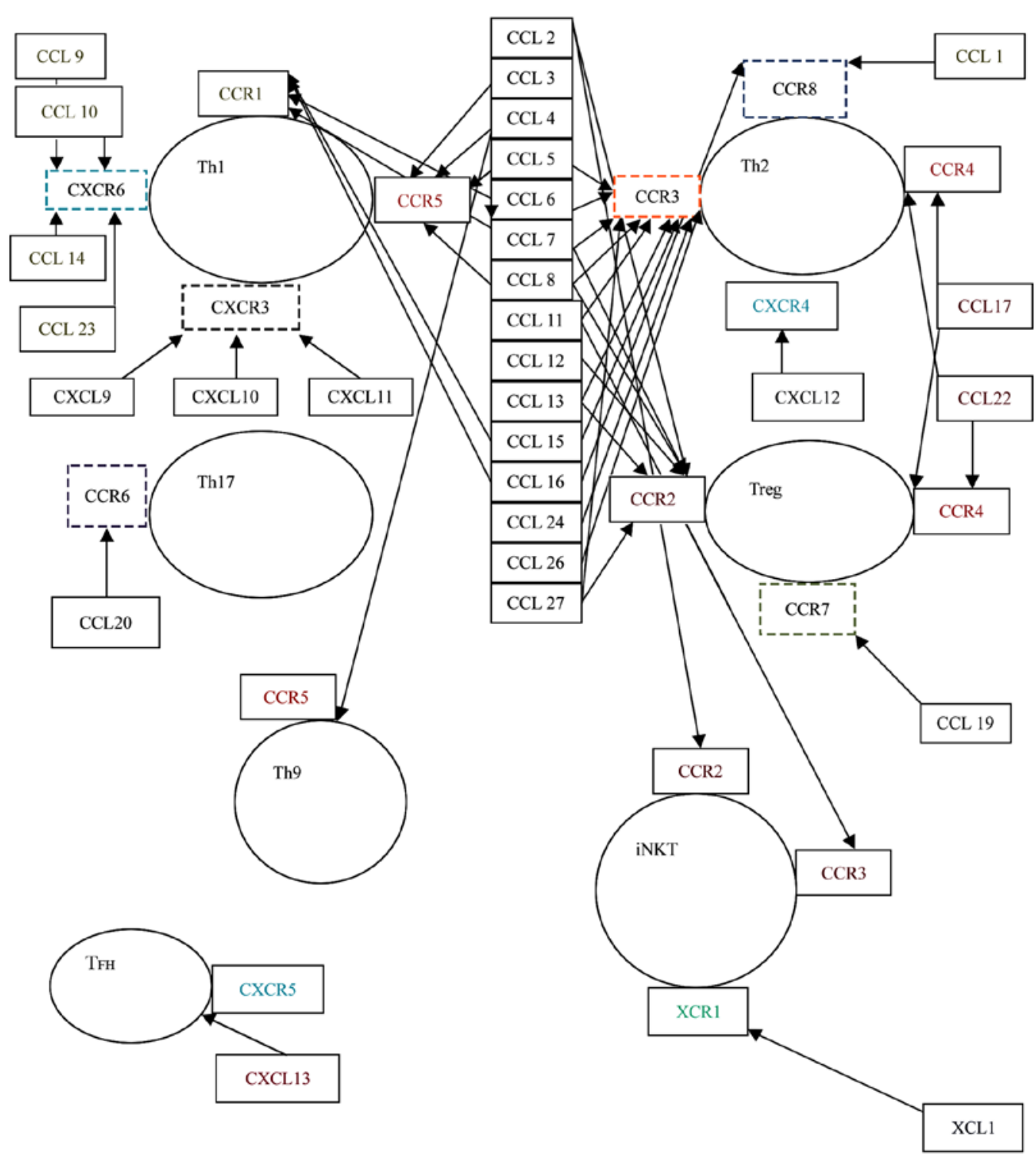

Figure 1. Interplay between chemokines and T cells. Th1, Th1 lymphocyte; Th2, Th2 lymphocyte; Th9, Th9 lymphocyte; Th17, Th17 lymphocyte; Treg, $\mathrm{T}$ regulatory lymphocytes; $\mathrm{T}_{\mathrm{FH}}$, $\mathrm{T}$ follicular helper cells; iNKT, invariant natural killer T; CCL, C-C motif ligand; CXCL, C-X-C-motif ligand; CCR, C-C receptor.

CCL25 [thymus-expressed chemokine (TECK)] and CCL27 [cutaneous T cell-attracting chemokine (CTAK)] (43).

The interrelations between $\mathrm{CC}$ and $\mathrm{T}$ cells are well established (43). The interaction between $\mathrm{CC}$, mediated by their receptors, and $\mathrm{T}$ cells is well documented, as well as this influence on the inflammatory infiltrate from allergic pathogenesis (43). Further, we will focus on the presentation of the interaction between the different subtypes of $\mathrm{T}$ cells and the $\mathrm{CC}$ regarding their contribution to the pathogenesis of respiratory allergies (Fig. 1).

Chemokines associated with Th2 lymphocyte function. Th2 cells are classically associated with the CC $(\beta)$ family (best studied until now are CCL1, CCL17, CCL18, CCL22) (43). They possess three receptors for CC: CCR3, CCR4, and CCR8. CCL1 (also known as I-309) is a potent attractant for Th2 lymphocytes (44). CCL1 represents the predominant CC secreted from IgE-activated mast cells and is found in high concentrations in asthmatic airways (45). Mast cells release of CCL1 was proposed to be the key step for early Th2 recruitment through the CCR8 receptor (46). CCL1 was found to be significantly elevated in the bronchoalveolar fluid (BALF) from atopic asthmatic patients as compared with volunteers (44), and asthmatic vs. controls (47). The role of CCL1 in the pathogenesis of asthma was indirectly demonstrated by the suppression of its serum levels after treating human monocytic leukemia cell line THP-1 and human monocytes from healthy donors with a cysteinyl leukotriene receptor antagonist (montelukast) (48). Murine studies reinforced the role of CCL1 released by mast cells and basophils and its receptor (CCR8) in recruitment of IL-4, IL-5 and IL-13-secreting T lymphocytes into the airways $(45,49)$.

CCL17 [thymus and activation regulated chemokine (TARC)] facilitates recruitment, activation and development of Th2-polarized cells that express CCR4 (50). CCL17 has been associated with an important role in the development 
of pulmonary diseases (51). Clinical studies that included patients with asthma demonstrated over-expression of CCL17 $\mathrm{RNAm}^{+}$in patients with asthma compared with controls and a weak, but significant association with sputum eosinophilia (52); RNAm ${ }^{+}$TARC/CCL17 cells were found elevated in the epithelium and submucosa of the bronchial biopsies of the asthmatics compared with the controls (53). CCL17 was also highly expressed in patients with AR or rhino-sinusitis in serum and nasal secretions compared with controls (54-57) and significantly decreased after immunotherapy in patients with dust mite allergy (50), suggesting an implication in nasosinusal allergy.

CCL18 [pulmonary and activation-regulated chemokine (PARC)] is another chemokine, production of which, is induced by the inflammatory Th2 cytokines. CCL18 exhibits dual functions, with pro- and anti-inflammatory properties, according to the environment (baseline or inflammatory) and to the genetic background. CCL18 recruits basophils and Th2 cells activates basophils and induces histamine release (58). CCL18 levels were found to be elevated in patients with asthma after segmental allergen challenge (59) and significantly correlated with sputum eosinophil percentages (60) in patients with dust mites allergy (61) and AR (62), results congruent with theoretical data.

CCL22 [monocyte-derived chemokine (MDC)] induces the selective migration of Th2 cells (roles in homing and recruitment of $\mathrm{CC}$ chemokine receptor 4-bearing Th2 cells in allergen-induced inflammation). High levels of CCL22 were found in the serum of patients with allergic rhinitis with sensitization to birch pollen (63) and ragweed pollen (56), which suggest a possible role in the pathogenesis of AR.

The Eotaxin family, which include Eotaxin-1 (CCL11), Eotaxin-2 (CCL24) and Eotaxin-3 (CCL26), recruits and activates CCR3-bearing cells, such as Th2 lymphocytes, mast cells and eosinophils that play an important role in allergic diseases (64). Eotaxin-1 was also shown to contribute in producing AHR. Eotaxin-1 presented elevated levels and good correlations with sputum eosinophilia in children with stable asthma compared with controls (65), and significant differences between children with asthma vs. healthy children in BAL fluid (66), which suggests that eotaxin-1 may regulate eosinophil trafficking into the airways of asthmatic children in a coordinated manner. High levels of eotaxin-1 were obtained after nasal allergen challenge in patients with AR comparing with controls (67) and in the material from nasal brushing in patients with asthma, allergic rhinitis and COPD (68). Eotaxin-1 was involved in acute allergic airway response to Aspergillus fumigatus (69), eosinophilic inflammation in asthma (70) and progress to AHR (71). Based on a review that included 30 studies, Eotaxin-1 was considered as a potentially useful biomarker for the diagnosis and assessment of asthma severity and control (72). Eotaxin-2, found in high levels in patients with nasal polyposis and perennial allergic rhinitis when comparing to controls, contribute to eosinophil attraction at the site of inflammation (73). Eotaxin-3 was expressed by nasal nerves of patients with AR after allergen challenge (74) and predisposed to AR in a Korean population (75).

Besides this known relationship between Th2 lymphocytes and presented chemokines, a number of studies pointed out the association of other $\mathrm{CC}$ and $\mathrm{Th} 2$ cells in the pathogenesis of respiratory allergic diseases. For instance, in the last decades, numerous studies focused on the investigation on CCL2 [monocyte chemoattractant protein-1 (MCP-1)], CCL5 (RANTES-regulated on activation, normal T cell expressed and secreted), CCL7 [monocyte-chemotactic protein-3 (MCP-3)], CCL13 [monocyte-chemotactic protein-4 (MCP-4)] and CX3CL1 (Fraktaline) regarding their association with inflammation in asthma and AR.

CCL2 was found to be related to the development of airway smooth muscle (ASM) hyperplasia in asthma (76) and has been proven to be a good biomarker of asthma control in adults and children when it is measured in saliva along with CCL5 (RANTES) (77). CCL2 (MCP-1) was observed in high serum levels in experimental murine studies of allergic asthma $(70,78)$ and in bronchoalveolar lavage (BAL) from a Cynomolgus monkey model (79). Genetic studies proved the association between $C C L 7$ and asthma: $-1382 \mathrm{~T} / \mathrm{C}$ was associated with the susceptibility to atopic asthma in an Indian population (80). CCL7 was associated to the deficiency of IL17-A and suppression of eosinophil infiltration in an animal model of AR (81). CCL5 (RANTES) was significantly higher in patients with atopic asthma than controls and positive correlated with absolute eosinophil counts and total serum $\operatorname{IgE}(82)$ in pediatric patients with asthma after exercise challenge (83), which seems to be associated with allergic inflammation. On the other hand, the levels of CCL5 presented significant differences between patients with allergic and non-allergic rhinopathies and polyps vs. those with normal mucosa (84), which suggest its contribution to leukocyte infiltration and activation related to inflammation. Two CCL5'SNPs (located at -403G/A and -28C/G) were evaluated and associated with the risk of asthma in Asian and Caucasian populations (85). CCL13 (MCP-4), a CC able to induce crucial immuno-modulatory responses through its effects on epithelial, muscular and endothelial cells was also measured in studies investigating asthma and rhinitis. Significant higher plasma levels of CCL13 were found in patients with stable-asthma than in controls and those with acute asthma vs. those with stable asthma (86). It was shown that the CCL13 expression was stimulated by IL-4, a cytokine characteristic for $\mathrm{Th} 2$, in an experimental study that used airway smooth muscle cells (87). Moreover, serum levels of CCL13 were observed to be higher in patients with allergic rhinitis after nasal allergen challenge between patients and controls and during natural pollen exposure (88).

CX3CL1 (Fraktaline) has been found to be increased in allergic diseases by promoting Th2 cell survival in the inflamed airways (particularly in asthma). CX3CL1 levels were increased after segmental allergen challenge in allergic asthmatic patients $(89,90)$. The CX3CL1/CX3CR1 axis was also demonstrated to contribute to the development of allergic asthma in murine studies (91).

Chemokines associated with function of Thl lymphocytes. Th1 lymphocytes are associated with CXC chemokines, especially CXCL9, 10 and 11 . Th1 lymphocytes possess the receptors CCR1, CCR5, CXCR3 and CXCR6 (43). Three CC-CXCL9 (MIG), CXCL10 (IP-10) and CXCL11 (ITAC) are described, which form a mini-cluster along the chromosome 
4 at q21.21. They are inducible by IFN- $\gamma$ and act on immune cells expressing CXCR3. Th1 cells express CXCR3 and thus will be attracted by these chemokines (92). CXCL9 and CXCL10 were released in large amounts by eosinophils obtained from the peripheral blood of allergic volunteers when these were stimulated concomitantly with TNF- $\alpha$ and IFN- $\gamma$ (93). Also, it was observed that high concentrations of CXCL9, 10 and 11 were significantly elevated (94) in BALF after broncho-provocation with antigen in patients with asthma. Allergen activation in asthma patients provoked a diminished production of CXCL9 and CXCL10, which contributed to a skewed Th2 profile (95). Elevated levels of CXCL9 and CXCL10 were observed in a pediatric study in patients with an acute exacerbation in contrast to patients with stable asthma (96). CXCL10 proved to be a useful inflammatory marker of occupational asthma (OA) exacerbation in patients with wood dust OA in contrast with healthy controls (97) and in the exacerbation of childhood asthma (96). CXCL10 presented significant differences in patients with AR when it was measured in nasal lavage before and after allergen exposure (98). The development of respiratory allergies was related to decreased levels of CXCL10, particularly in patients with asthma, because this situation indirectly favors Th2 cytokines production (99-101).

Chemokines associated with function of Th17 lymphocytes. Th17 lymphocytes were found to be associated with chemokines from the CXC family: CXCL1 (GRO $\alpha$ ), CXCL2 (GRO $\beta$ ), CXCL3 (GRO $\gamma$ ), CXCL5 [epithelial-derived neutrophil-activating peptide 78 (ENA-78)], CXCL6 [granulocyte chemotactic protein 2 (GCP2)] and CXCL8 (IL-8) (43). These chemokines, along with CXCL7, belong to the family of ELR+CXC chemokines (characterized by the highly conserved $\mathrm{N}$-terminal ELR (glutamic acid-leucine-arginine) triad and agonists for the CXCR2 receptor. Their primary role is to attract and activate neutrophils (102). Besides these well-known properties, a small number of studies associated these chemokines with allergic inflammation. An important body of evidence related to the contribution of these chemokines regarding allergic inflammation in respiratory diseases was obtained through experimental animal murine models. Thus, it was observed that CXCL1, a chemokine expressed on macrophages, neutrophils and epithelial cells known for its role in angiogenesis, arteriogenesis, inflammation, wound healing, and tumorigenesis had an increased expression in mouse lung epithelial cells in sensitized animals with Anisakis, which suggest that allergens can induce airway inflammation by elevating Th2 and Th17 responses (103). In addition, it was found that its concentration was increased in the BAL of cockroach-sensitized mice where the allergen was administered intranasally during a period of 5 days, which shows that CXCL1 might have roles in the remodeling during asthma (71). The expression of CXCL1 was decreased in a murine model of AR when the experimental animals were treated with flagellin-ovalbumin mixture (used as an adjuvant for immunomodulation) (104) and in a murine model of allergic severe asthma sensitization with house dust mites (HDM) when the researchers blocked the activity of IL17-A and IL17-F, which suggest that CXCL1 might be an important player in neutrophilic allergic lung inflammation (105).
The contribution of CXCL2 and CXCL3 to mediating normal and asthmatic airway smooth muscle cell (ASMC) migration (through the ERK1/2 MAPK pathway) was demonstrated in a study that used human ASMCs isolated from lung transplant donors, which suggest a possible role in the pathogenesis of airway remodeling in asthma (106).

CXCL8 (interleukin-8) is the primary cytokine involved in the recruitment of neutrophils to the site of damage or infection, representing one of the key mediators associated with inflammation. In some situations, IL-8-stimulated neutrophils could lead eosinophils to accumulate in the airways of asthma (107). IL-8 seems to contribute to the pathophysiology of allergic diseases through its roles in some aspects of these mechanisms. Serum IL-8 levels were higher in patients with asthma (non-allergic and allergic) compared with controls in a genetic study from Spain in adults (108) and in a pediatric population from Tunisia (109) due to the roles in neutrophil functions (release, chemotaxis, survival). Serum levels of IL-8 were significantly higher in patients with allergic asthma compared with allergic rhinitis and controls (110), suggesting that IL-8 is associated with more severe inflammatory response. In addition, higher levels of IL-8 were found in BALF of asthmatic patients compared with healthy controls, the authors proposed that IL-8 might augment eosinophil trans-basement membrane migration by releasing superoxide anion, matrix metalloproteinase, leukotriene B4, and platelet-activating factor (111). Elevated concentrations of IL- 8 were found in patients with AR/chronic sino-sinusitis and concomitant nasal polyps $(112,113)$. IL-8 levels were higher in nasal biopsy specimens from patients with persistent AR vs. controls (114). Pelikan demonstrated high concentrations of IL-8 in tears from patients with AR after nasal provocation tests with allergen $(115,116)$. In conclusion, IL-8 is a key player in the pathogenesis of asthma through its roles in neutrophil functions.

Moreover, it was shown that not only is allergic sensitization related to elevated levels of IL-8, but it is also related to pollution. For instance, it was found that diesel exhaust particles (DEP) induce expression of IL-8 in nasal fibroblasts (117) and in primary nasal epithelial cells (NECs) (118), suggesting that air pollution might induce or aggravate allergic rhinitis through this chemokine (117).

Chemokines associated with other types of lymphocytes. Th9 lymphocytes. CCL4 was significantly associated with a mix of lymphocytes (Th1, Th2, Th9, Th17) in subjects with severe asthma (119).

$\mathrm{T}_{\mathrm{FH}}$ lymphocytes. The plasma levels of CXCL13 were significantly elevated and correlated with a subset of $\mathrm{T}_{\mathrm{FH}}$ cells: $\mathrm{T}_{\mathrm{FH} 2}$ in patients with atopic asthma (120).

iNKT lymphocytes. A number of studies connected $\beta$ and $\delta$ families of chemokines with these lymphocytes. NKT cells previously treated with CCL2 in contact with naïve T cells determined them to produce IL-4 in a murine study (121). Another murine study demonstrated that the stimulation of NKT cells with a specific ligand- $\alpha$-galactosylceramide enhanced ragweed-induced IL- 4 and CCL11 production (122). The duet CCR2/CCL2 was reduced in control mice vs. OVA-sensitized mice in a study that evaluated the expression of CD1d, an MHC-1 like molecule, responsible for 
presenting glycolipids to iTCR and iNKT cells conducting exacerbate airway inflammation and up-regulating $\operatorname{IgE}$ production (123). Along with other proteins, CXCL15 contributed to iNKT regulated AHR via altering leukocyte chemotaxis in a murine study (124). Data from animal studies (murine) demonstrate that iNKT cell-mediated XCL1-XCR1 axis promotes AHR by recruiting $\mathrm{CD}_{103}{ }^{+} \mathrm{DCs}$ into the lung in patients with allergic asthma (125).

\section{Conclusions}

Interleukins were used in the last two decades in order to define and characterize the classical Th2/non-Th2 endotype, as well as the newest Th2/Th17. As shown, CCs appear to be good candidates for a comprehensive characterization of endotypes.

\section{Acknowledgements}

Professional editing, linguistic and technical assistance was provided by Irina Radu, Individual Service Provider, certified translator in Medicine and Pharmacy (certificate credentials: Series E no. 0048).

\section{Funding}

No funding was received.

\section{Availability of data and material}

All data generated or analyzed during this study are included in this published article.

\section{Authors' contributions}

NOB contributed substantially to the conception and design of the study, the acquisition, analysis and interpretation of the data, and was involved in the drafting of the manuscript. MD and RSC contributed substantially to the acquisition, analysis and interpretation of the data and were involved in the drafting of the manuscript. DV, RCC, ASP, RC, CT and CG contributed substantially to the acquisition of the data and were involved in the critical revisions of the manuscript for important intellectual content. All authors agreed to be accountable for all aspects of the work in ensuring that questions related to the accuracy or integrity of any part of the work are appropriately investigated and resolved. All the authors read and approved the final version of the manuscript.

\section{Ethics approval and consent to participate}

No applicable.

\section{Patient consent for publication}

Not applicable.

\section{Competing interests}

The authors declare that they have no competing interests.

\section{References}

1. Yii AC, Tay TR, Choo XN, Koh MS, Tee AK and Wang DY: Precision medicine in united airways disease: A 'treatable traits' approach. Allergy 73: 1964-1978, 2018.

2. Lötvall J, Akdis CA, Bacharier LB, Bjermer L, Casale TB, Custovic A, Lemanske RF Jr, Wardlaw AJ, Wenzel SE and Greenberger PA: Asthma endotypes: A new approach to classification of disease entities within the asthma syndrome. J Allergy Clin Immunol 127: 355-360, 2011.

3. Desai M and Oppenheimer J: Elucidating asthma phenotypes and endotypes: Progress towards personalized medicine. Ann Allergy Asthma Immunol 116: 394-401, 2016.

4. Muraro A, Lemanske RF Jr, Hellings PW, Akdis CA, Bieber T, Casale TB, Jutel M, Ong PY,Poulsen LK, Schmid-Grendelmeier P, et al: Precision medicine in patients with allergic diseases: Airway diseases and atopic dermatitis-PR ACTALL document of the European Academy of Allergy and Clinical Immunology and the American Academy of Allergy, Asthma \& Immunology. J Allergy Clin Immunol 137: 1347-1358, 2016.

5. Agache I and Akdis CA: Precision medicine and phenotypes, endotypes, genotypes, regiotypes, and theratypes of allergic diseases. J Clin Invest 129: 1493-1503, 2019.

6. Wambre E, Bajzik V, DeLong JH, O'Brien K, Nguyen QA, Speake C, Gersuk VHH, DeBerg HA, Whalen E, Ni C, et al: A phenotypically and functionally distinct human $\mathrm{TH} 2$ cell subpopulation is associated with allergic disorders. Sci Transl Med 9: eaam9171, 2017.

7. Velez TE, Swartzendruber JA, Hulse KE and Bryce PJ: Regulation of B cell responses in allergy by histamine receptors. J Immunol 196: 123.13, 2016.

8. Kiniwa T, Enomoto Y, Terazawa N, Omi A, Miyata N, Ishiwata K and Miyajima A: NK cells activated by interleukin-4 in cooperation with interleukin-15 exhibit distinctive characteristics. Proc Natl Acad Sci USA 113: 10139-10144, 2016.

9. Singh AK, Rhost S, Löfbom L and Cardell SL: Defining a novel subset of CD1d-dependent type II natural killer T cells using natural killer cell-associated markers. Scand J Immunol 90: e12794, 2019.

10. Chen F, Hong H, Sun Y, Hu X, Zhang J, Xu G, Zhao W, Li H and Shi J: Nasal interleukin 25 as a novel biomarker for patients with chronic rhinosinusitis with nasal polyps and airway hypersensitiveness: A pilot study. Ann Allergy Asthma Immunol 119: 310-316.e2, 2017.

11. Baumann R, Rabaszowski M, Stenin I, Gaertner-Akerboom M, Scheckenbach K, Wiltfang J, Schipper J and Wagenmann M: The release of IL-31 and IL-13 after nasal allergen challenge and their relation to nasal symptoms. Clin Transl Allergy 2: 13, 2012.

12. Nechama M, Kwon J, Wei S, Kyi AT, Welner RS, Ben-Dov IZ, Arredouani MS, Asara JM, Chen $\mathrm{CH}$, Tsai CY, et al: The IL-33-PIN1-IRAK-M axis is critical for type 2 immunity in IL-33-induced allergic airway inflammation. Nat Commun 9: $1603,2018$.

13. Meng Q, Liu X, Li P, He L, Xie J, Gao X, Wu X, Su F and Liang Y: The influence of house dust mite sublingual immunotherapy on the TSLP-OX40L signaling pathway in patients with allergic rhinitis. Int Forum Allergy Rhinol 6: 862-870, 2016.

14. Fahy JV: Type 2 inflammation in asthma - present in most, absent in many. Nat Rev Immunol 15: 57-65, 2015.

15. Ciebiada M, Barylski M and Gorska Ciebiada M: Nasal eosinophilia and serum soluble intercellular adhesion molecule 1 in patients with allergic rhinitis treated with montelukast alone or in combination with desloratadine or levocetirizine. Am J Rhinol Allergy 27: e58-e62, 2013.

16. Kralimarkova TZ, Popov TA, Staevska M, Mincheva R, Lazarova C, Racheva R, Mustakov TB, Filipova V, Koleva M, Bacheva K, et al: Objective approach for fending off the sublingual immunotherapy placebo effect in subjects with pollenosis: Double-blinded, placebo-controlled trial. Ann Allergy Asthma Immunol 113: 108-113, 2014.

17. Diamant $Z$ and Hanania NA: Editorial: The new look on asthma: linking phenotypes, endotypes and biomarkers to asthma management. Curr Opin Pulm Med 22: 1-2, 2016.

18. Chakir J, Shannon J, Molet S, Fukakusa M, Elias J, Laviolette M, Boulet LP and Hamid Q: Airway remodeling-associated mediators in moderate to severe asthma: Effect of steroids on TGF-beta, IL-11, IL-17, and type I and type III collagen expression. J Allergy Clin Immunol 111: 1293-1298, 2003. 
19. Barczyk A, Pierzchala W and Sozañska E: Interleukin-17 in sputum correlates with airway hyperresponsiveness to methacholine. Respir Med 97: 726-733, 2003.

20. Staton TL, Peng K, Owen R, Choy DF, Cabanski CR, Fong A, Brunstein F, Alatsis KR and Chen H: A phase I, randomized, observer-blinded, single and multiple ascending-dose study to investigate the safety, pharmacokinetics, and immunogenicity of BITS7201A, a bispecific antibody targeting IL-13 and IL-17, in healthy volunteers. BMC Pulm Med 19: 5, 2019.

21. Al-Kufaidy R, Vazquez-Tello A, BaHammam AS, Al-Muhsen S, Hamid Q and Halwani R: IL-17 enhances the migration of B cells during asthma by inducing CXCL13 chemokine production in structural lung cells. J Allergy Clin Immunol 139: 696-699.e5, 2017.

22. Chambers ES, Nanzer AM, Pfeffer PE, Richards DF, Timms PM, Martineau AR, Griffiths CJ, Corrigan CJ and Hawrylowicz CM: Distinct endotypes of steroid-resistant asthma characterized by IL-17A(high) and IFN- $\gamma$ (high) immunophenotypes: Potential benefits of calcitriol. J Allergy Clin Immunol 136: 628-637.e4, 2015.

23. Berry MA, Hargadon B, Shelley M,Parker D, Shaw DE, Green RH, Bradding P, Brightling CE, Wardlaw AJ and Pavord ID: Evidence of a role of tumor necrosis factor alpha in refractory asthma. $\mathrm{N}$ Engl J Med 354: 697-708, 2006.

24. Widegren H, Erjefält J, Korsgren M, Andersson M and Greiff L: Effects of intranasal TNFalpha on granulocyte recruitment and activity in healthy subjects and patients with allergic rhinitis. Respir Res 9: 15, 2008.

25. Hew KM, Walker AI, Kohli A, Garcia M, Syed A, McDonaldHyman C, Noth EM, Mann JK, Pratt B, Balmes J, et al: Childhood exposure to ambient polycyclic aromatic hydrocarbons is linked to epigenetic modifications and impaired systemic immunity in $\mathrm{T}$ cells. Clin Exp Allergy 45: 238-248, 2015.

26. Irvin C, Zafar I, Good J, Rollins D, Christianson C, Gorska MM, Martin RJ and Alam R: Increased frequency of dual-positive TH2/TH17 cells in bronchoalveolar lavage fluid characterizes a population of patients with severe asthma. J Allergy Clin Immunol 134: 1175-1186.e7, 2014.

27. Farahani R, Sherkat R, Hakemi MG, Eskandari N and Yazdani R: Cytokines (interleukin-9, IL-17, IL-22, IL-25 and IL-33) and asthma. Adv Biomed Res 3: 127, 2014.

28. Kearley J, Erjefalt JS, Andersson C, Benjamin E, Jones CP, Robichaud A, Pegorier S, Brewah Y, Burwell TJ, Bjermer L, et al: IL-9 governs allergen-induced mast cell numbers in the lung and chronic remodeling of the airways. Am J Respir Crit Care Med 183: 865-875, 2011.

29. Tang J, Xiao P, Luo X, Bai J, Xia W, Chen W, Li J, Yu Q, Shi S, $\mathrm{Xu}$ Y, et al: Increased IL-22 level in allergic rhinitis significantly correlates with clinical severity. Am J Rhinol Allergy 28: 197-201, 2014

30. Besnard AG, Sabat R, Dumoutier L, Renauld JC, Willart M, Lambrecht B, Teixeira MM, Charron S, Fick L, Erard F, et al: Dual Role of IL-22 in allergic airway inflammation and its cross-talk with IL-17A. Am J Respir Crit Care Med 183: 1153-1163, 2011.

31. Linden M, Svensson C, Andersson M, Greiff L, Andersson E, Denburg JA and Persson CG: Circulating eosinophil/basophil progenitors and nasal mucosal cytokines in seasonal allergic rhinitis. Allergy 54: 212-219, 1999.

32. Gong F, Zheng T and Zhou P: T follicular helper cell subsets and the associated cytokine IL-21 in the pathogenesis and therapy of asthma. Front Immunol 10: 2918, 2019.

33. Gong F, Qian C, Zhu H, Zhu J, Pan Y, Dong Q and Jiang D: Circulating follicular T-helper cell subset distribution in patients with asthma. Allergy Asthma Proc 37: 154-161, 2016.

34. Gong F, Zhu HY, Zhu J, Dong QJ, Huang X and Jiang DJ: Circulating $\mathrm{CXCR}^{+} \mathrm{CD}^{+} \mathrm{T}$ cells participate in the IgE accumulation in allergic asthma. Immunol Lett 197: 9-14, 2018.

35. Lezmi $\mathrm{G}$ and Leite-de-Moraes M: Invariant natural killer $\mathrm{T}$ and mucosal-associated invariant T cells in asthmatic patients. Front Immunol 9: 1766, 2018.

36. Kurioka A, Jahun AS, Hannaway RF, Walker LJ, Fergusson JR, Sverremark-Ekström E, Corbett AJ, Ussher JE, Willberg CB and Klenerman P: Shared and distinct phenotypes and functions of human $\mathrm{CD}_{161^{++}} \mathrm{v}$ alpha $7.2^{+} \mathrm{T}$ cell subsets. Front Immunol 8: 1031, 2017.

37. Lezmi G, Abou Taam R, Dietrich C, Chatenoud L, de Blic J and Leite-de-Moraes M: Circulating IL-17-producing mucosal-associated invariant T cells (MAIT) are associated with symptoms in children with asthma. Clin Immunol 188: 7-11, 2018.
38. Krawczyk CM, Shen H and Pearce EJ: Functional plasticity in memory T helper cell responses. J Immunol 178: 4080-4088, 2007.

39. Filì L, Ferri S, Guarna F, Sampognaro S, Manuelli C, Liotta F, Cosmi L, Matucci A, Vultaggio A and Annunziato F: Redirection of allergen-specific $\mathrm{TH} 2$ responses by a modified adenine through Toll-like receptor 7 interaction and IL-12/IFN release. J Allergy Clin Immunol 118: 511-517, 2006.

40. Veldhoen M, Uyttenhove C, van Snick J,Helmby H, Westendorf A, Buer J, Martin B, Wilhelm C and Stockinger B: Transforming growth factor-beta 'reprograms' the differentiation of T helper 2 cells and promotes an interleukin 9-producing subset. Nat Immunol 9: 1341-1346, 2008.

41. Hegazy AN, Peine M, Helmstetter C, Panse I, Fröhlich A, Bergthaler A, Flatz L, Pinschewer DD, Radbruch A and Löhning M: Interferons direct $\mathrm{Th} 2$ cell reprogramming to generate a stable GATA-3(+)T-bet(+) cell subset with combined Th2 and Th1 cell functions. Immunity 32: 116-128, 2010.

42. Panzer M, Sitte S, Wirth S, Drexler I, Sparwasser T and Voehringer D: Rapid in vivo conversion of effector T cells into Th2 cells during helminth infection. J Immunol 188: 615-623, 2012.

43. Adkinson NF, Bochner BS, Burks AW, Busse WW, Holgate ST, Lemanske RF and O'Hehir RE: Chapter 7. Chemokines in Middleton's Allergy. In: Principles and Practice. Vol. 1. 8th edition. Elsevier Saunders, Philadelphia, pp98-112, 2014.

44. Montes-Vizuet R, Vega-Miranda A, Valencia-Maqueda E, Negrete-García MC, Velásquez JR and Teran LM: CC chemokine ligand 1 is released into the airways of atopic asthmatics. Eur Respir J 28: 59-67, 2006.

45. Gonzalo JA, Qiu Y,Lora JM, Al-Garawi A, Villeval JL, Boyce JA, Martinez-A C, Marquez G, Goya I, Hamid Q, et al: Coordinated involvement of mast cells and T cells in allergic mucosal inflammation: Critical role of the CC chemokine ligand 1:CCR8 axis. J Immunol 179: 1740-1750, 2007.

46. Islam SA and Luster AD: T cell homing to epithelial barriers in allergic disease. Nat Med 18: 705-715, 2012.

47. Mutalithas K, Guillen C, Raport C, Kolbeck R, Soler D, Brightling CE, Pavord ID and Wardlaw AJ: Expression of CCR8 is increased in asthma. Clin Exp Allergy 40: 1175-1185, 2010.

48. Lin YC, Huang MY, Lee MS, Hsieh CC, Kuo HF, Kuo CH and Hung $\mathrm{CH}$ : Effects of montelukast on M2-related cytokine and chemokine in M2 macrophages. J Microbiol Immunol Infect 51: 18-26, 2018.

49. Chhiba KD, Hsu CL, Berdnikovs S and Bryce PJ: Transcriptional heterogeneity of mast cells and basophils upon activation. J Immunol 198: 4868-4878, 2017.

50. Takeuchi H, Yamamoto Y, Kitano $\mathrm{H}$ and Enomoto T: Changes in thymus- and activation-regulated chemokine (TARC) associated with allergen immunotherapy in patients with perennial allergic rhinitis. J Investig Allergol Clin Immunol 15: 172-176, 2005.

51. Teplyakov A, Obmolova G and Gilliland GL: Structural insights into chemokine CCL17 recognition by antibody M116. Biochem Biophys Rep 13: 27-31, 2017.

52. Staples KJ, Hinks TS, Ward JA, Gunn V, Smith C and Djukanović R: Phenotypic characterization of lung macrophages in asthmatic patients: Overexpression of CCL17. J Allergy Clin Immunol 130: 1404-12.e7, 2012.

53. Ying S, O'Connor B, Ratoff J, Meng Q, Mallett K, Cousins D, Robinson D, Zhang G, Zhao J, Lee TH, et al: Thymic stromal lymphopoietin expression is increased in asthmatic airways and correlates with expression of Th2-attracting chemokines and disease severity. J Immunol 174: 8183-8190, 2005.

54. Chen YL and Chiang BL: Targeting TSLP with shRNA alleviates airway inflammation and decreases epithelial CCL17 in a murine model of asthma. Mol Ther Nucleic Acids 5: e316, 2016.

55. Xiao JZ, Kondo S, Takahashi N, Odamaki T, Iwabuchi N, Miyaji K, Iwatsuki K and Enomoto T: Changes in plasma TARC levels during Japanese cedar pollen season and relationships with symptom development. Int Arch Allergy Immunol 144: 123-127, 2007.

56. Sun J, Wong B, Cundall M, Goncharova S, Conway M, Dalrymple A, Coyle AJ, Waserman S and Jordana M: Immunoreactivity profile of peripheral blood mononuclear cells from patients with ragweed-induced allergic rhinitis. Clin Exp Allergy 37: 901-908, 2007.

57. Tsybikov NN, Egorova EV, Kuznik BI, Fefelova EV and Magen E: Biomarker assessment in chronic rhinitis and chronic rhinosinusitis: Endothelin-1, TARC/CCL17, neopterin, and $\alpha$-defensins. Allergy Asthma Proc 37: 35-42, 2016. 
58. Chenivesse C and Tsicopoulos A: CCL18 - Beyond chemotaxis. Cytokine 109: 52-56, 2018.

59. Gavala ML, Kelly EA, Esnault S, Kukreja S, Evans MD, Bertics PJ, Chupp GL and Jarjour NN: Segmental allergen challenge enhances chitinase activity and levels of CCL18 in mild atopic asthma. Clin Exp Allergy 43: 187-197, 2013.

60. Kim HB, Kim CK, Iijima K, Kobayashi T and Kita H: Protein microarray analysis in patients with asthma: Elevation of the chemokine PARC/CCL18 in sputum. Chest 135: 295-302, 2009.

61. de Nadaï P, Charbonnier AS, Chenivesse C, Sénéchal S, Fournier C, Gilet J, Vorng H, Chang Y, Gosset P, Wallaert B et al: Involvement of CCL18 in allergic asthma. J Immunol 176: 6286-6293, 2006.

62. Peterson S, Poposki JA, Nagarkar DR, Chustz RT, Peters AT, Suh LA, Carter R, Norton J, Harris KE, Grammer LC, et al: Increased expression of $\mathrm{CC}$ chemokine ligand 18 in patients with chronic rhinosinusitis with nasal polyps. J Allergy Clin Immunol 129: 119-27.e1, 9, 2012.

63. Yanai M, Sato K, Aoki N, Takiyama Y, Oikawa K, Kobayashi H, Kimura S, Harabuchi Y and Tateno M: The role of CCL22/ macrophage-derived chemokine in allergic rhinitis. Clin Immunol 125: 291-298, 2007.

64. Holgate ST and Davies DE: Rethinking the pathogenesis of asthma. Immunity 31: 362-367, 2009.

65. Kim CK, Kita H, Callaway Z, Kim HB, Choi J, Fujisawa T, Shin BM and Koh YY: The roles of a Th2 cytokine and CC chemokine in children with stable asthma: Potential implication in eosinophil degranulation. Pediatr Allergy Immunol 21: e697-e704, 2010

66. Rojas-Ramos E, Avalos AF, Pérez-Fernandez L, CuevasSchacht F, Valencia-Maqueda E and Terán LM: Role of the chemokines RANTES, monocyte chemotactic proteins-3 and -4, and eotaxins- 1 and -2 in childhood asthma. Eur Respir J 22: 310-316, 2003

67. Semik-Orzech A, Barczyk A, Wiaderkiewicz R and Pierzchała W: Eotaxin, but not IL-8, is increased in upper and lower airways of allergic rhinitis subjects after nasal allergen challenge. Allergy Asthma Proc 32: 230-238, 2011.

68. Paplińska-Goryca M,Nejman-Gryz P, Górska K, Białek1-GoskK, Hermanowicz-Salamon J and Krenke R: Expression of inflammatory mediators in induced sputum: Comparative study in asthma and COPD. Adv Exp Med Biol 1040: 101-112, 2018.

69. Schuh JM, Blease K, Kunkel SL and Hogaboam CM Eotaxin/CCL11 is involved in acute, but not chronic, allergic airway responses to Aspergillus fumigatus. Am J Physiol Lung Cell Mol Physiol 283: L198-L204, 2002.

70. Mori A, Ogawa K, Kajiyama Y, Suko M and Kaminuma O Th2-cell-mediated chemokine synthesis is involved in allergic airway inflammation in mice. Int Arch Allergy Immunol 140 (Suppl 1): 55-58, 2006.

71. Arizmendi NG, Abel M, Puttagunta L, Asaduzzaman M Davidson C, Karimi K, Forsythe P and Vliagoftis H: Mucosal exposure to cockroach extract induces allergic sensitization and allergic airway inflammation. Allergy Asthma Clin Immunol 7: $22,2011$.

72. Wu D, Zhou J, Bi H, Li L, Gao W, Huang M, Adcock IM, Barnes PJ and Yao X: CCL11 as a potential diagnostic marker for asthma? J Asthma 51: 847-854, 2014.

73. Špadijer Mirković C, Perić A, Vukomanović Đurđević B and Vojvodić D: Effects of fluticasone furoate nasal spray on parameters of eosinophilic inflammation in patients with nasal polyposis and perennial allergic rhinitis. Ann Otol Rhinol Laryngol 126: 573-580, 2017.

74. Thornton MA, Akasheh N, Walsh MT, Moloney M, Sheahan PO, Smyth CM, Walsh RM, Morgan RM, Curran DR, Walsh MT, et al: Eosinophil recruitment to nasal nerves after allergen challenge in allergic rhinitis. Clin Immunol 147: 50-57, 2013.

75. Chae SC, Park YR, Oh GJ, Lee JH and Chung HT: The suggestive association of eotaxin-2 and eotaxin-3 gene polymorphisms in Korean population with allergic rhinitis. Immunogenetics 56: 760-764, 2005

76. Singh SR, Sutcliffe A, Kaur D, Gupta S, Desai D, Saunders R and Brightling CE: CCL2 release by airway smooth muscle is increased in asthma and promotes fibrocyte migration. Allergy 69: 1189-1197, 2014.

77. Little FF, Delgado DM, Wexler PJ, Oppenheim FG, Mitchell P, Feldman JA, Walt DR, Peng RD and Matsui EC: Salivary inflammatory mediator profiling and correlation to clinical disease markers in asthma. PLoS One 9: e84449, 2014.
78. Simons B, Ferrini ME, Carvalho S, Bassett DJ, Jaffar Z and Roberts K: PGI 2 controls pulmonary NK cells that prevent airway sensitization to house dust mite allergen. J Immunol 198: 461-471, 2017.

79. Mellado M, Martín de Ana A, Gómez L, Martínez C and Rodríguez-Frade JM: Chemokine receptor 2 blockade prevents asthma in a cynomolgus monkey model. J Pharmacol Exp Ther 324: 769-775, 2008.

80. Batra J, Das S, Chatterjee R, Chandra S and Ghosh B: Monocyte chemotactic protein (MCP3) promoter polymorphism is associated with atopic asthma in the Indian population. J Allergy Clin Immunol 128: 239-242.e3, 2011.

81. Zhang YL, Han DH, Kim DY, Lee CH and Rhee CS: Role of Interleukin-17A on the chemotactic responses to CCL7 in a murine allergic rhinitis model. PLoS One 12: e0169353, 2017.

82. Saad-El-Din Bessa S, Abo El-Magd GH and Mabrouk MM: Serum chemokines RANTES and monocyte chemoattractant protein-1 in Egyptian patients with atopic asthma: Relationship to disease severity. Arch Med Res 43: 36-41, 2012.

83. Keskin O, Keskin M, Kucukosmanoglu E, Ozkars MY Gogebakan B, Kul S, Bayram H and Coskun Y: Exhaled RANTES and interleukin 4 levels after exercise challenge in children with asthma. Ann Allergy Asthma Immunol 109: 303-308, 2012.

84. Marcella R, Croce A, Moretti A, Barbacane RC, Di Giocchino M and Conti P: Transcription and translation of the chemokines RANTES and MCP-1 in nasal polyps and mucosa in allergic and non-allergic rhinopathies. Immunol Lett 90: 71-75, 2003.

85. Xie ZK, Zhao H, Huang J and Xie ZF: The regulated upon activation normal T-cell expressed and secreted (RANTES) -28C/G and $-403 \mathrm{G} / \mathrm{A}$ polymorphisms and asthma risk: A meta-analysis. Mol Diagn Ther 18: 523-531, 2014

86. Kalayci O, Sonna LA, Woodruff PG, Camargo CA Jr, Luster AD and Lilly CM: Monocyte chemotactic protein-4 (MCP-4; CCL-13): A biomarker of asthma. J Asthma 41: 27-33, 2004.

87. Odaka M, Matsukura S, Kuga H, Kokubu F, Kasama T, Kurokawa M, Kawaguchi M, Ieki K, Suzuki S, Watanabe S, et al: Differential regulation of chemokine expression by Th1 and Th2 cytokines and mechanisms of eotaxin/CCL-11 expression in human airway smooth muscle cells. Int Arch Allergy Immunol 143 (Suppl 1): 84-88, 2007.

88. Baumann R, Rabaszowski M,Stenin I, TilgnerL, Scheckenbach K, Wiltfang J, Schipper J, Chaker A and Wagenmann M: Comparison of the nasal release of IL-4, IL-10, IL-17, CCL13/MCP-4, and CCL26/eotaxin-3 in allergic rhinitis during season and after allergen challenge. Am J Rhinol Allergy 27: 266-272, 2013.

89. Rimaniol AC, Till SJ, Garcia G, Capel F, Godot V, Balabanian K, Durand-Gasselin I, Varga EM, Simonneau G, Emilie D, et al: The CX3C chemokine fractalkine in allergic asthma and rhinitis. J Allergy Clin Immunol 112: 1139-1146, 2003.

90. El-Shazly A, Berger P, Girodet PO, Ousova O, Fayon M, Vernejoux JM, Marthan R and Tunon-de-Lara JM: Fraktalkine produced by airway smooth muscle cells contributes to mast cell recruitment in asthma. J Immunol 176: 1860-1868, 2006.

91. Mionnet C, Buatois V, Kanda A, Milcent V, Fleury S, Lair D, Langelot M, Lacoeuille Y, Hessel E, Coffman R, et al: CX3CR1 is required for airway inflammation by promoting $\mathrm{T}$ helper cell survival and maintenance in inflamed lung. Nat Med 16: 1305-1312, 2010

92. Kaplan AP: Chemokines, chemokine receptors and allergy. Int Arch Allergy Immunol 124: 423-431, 2001.

93. Liu LY, Bates ME, Jarjour NN, Busse WW, Bertics PJ and Kelly EA: Generation of Th1 and Th2 chemokines by human eosinophils: Evidence for a critical role of TNF- $\alpha$. J Immunol 179: 4840-4848, 2007.

94. Liu L, Jarjour NN, Busse WW and Kelly EA: Enhanced generation of helper T type 1 and 2 chemokines in allergen-induced asthma. Am J Respir Crit Care Med 169: 1118-1124, 2004.

95. Lun SW, Wong CK, Ko FW, Ip WK, Hui DS and Lam CW: Aberrant expression of $\mathrm{CC}$ and $\mathrm{CXC}$ chemokines and their receptors in patients with asthma. J Clin Immunol 26: 145-152, 2006

96. Lai ST, Hung CH, Hua YM, Hsu SH, Jong YJ and Suen JL: T-helper 1-related chemokines in the exacerbation of childhood asthma. Pediatr Int 50: 99-102, 2008.

97. Ragusa F and Fallahi P: IP-10 in occupational asthma: Review of the literature and case-control study. Clin Ter 168: e151-e157, 2017.

98. Tworek D, Kuna P, Młynarski W, Górski P, Pietras T and Antczak A: MIG (CXCL9), IP-10 (CXCL10) and I-TAC (CXCL11) concentrations after nasal allergen challenge in patients with allergic rhinitis. Arch Med Sci 9: 849-853, 2013. 
99. RomagnaniP,MaggiL,Mazzinghi B,CosmiL,Lasagni L,LiottaF, Lazzeri E, Angeli R, Rotondi M and Filì L: CXCR3-mediated opposite effects of CXCL10 and CXCL4 on TH1 or TH2 cytokine production. J Allergy Clin Immunol 116: 1372-1379, 2005.

100. Ko FW, Lun SW, Wong CK, Szeto CC, Lam CW, Leung TF and Hui DS: Decreased T-bet expression and changes in chemokine levels in adults with asthma. Clin Exp Immunol 147: 526-532, 2007.

101.Lun SW, Wong CK, Ko FW, Ip WK, Hui DS and Lam CW: Aberrant expression of $\mathrm{CC}$ and $\mathrm{CXC}$ chemokines and their receptors in patients with asthma. J Clin Immunol 26: 145-152, 2006.

102. Sawant KV, Poluri KM, Dutta AK, Sepuru KM, Troshkina A, Garofalo RP and Rajarathnam K: Chemokine CXCL1 mediated neutrophil recruitment: Role of glycosaminoglycan interactions. Sci Rep 6: 33123, 2016.

103. Cho MK, Park MK, Kang SA, Caballero ML, Perez-Pinar T, Rodriguez-Perez R, Ock MS, Cha HJ, Hong YC and Yu HS: Allergenicity of two Anisakis simplex allergens evaluated in vivo using an experimental mouse model. Exp Parasitol 146: 71-77, 2014.

104. Kim EH, Kim JH, SamivelR, Bae JS, Chung YJ, Chung PS, Lee SE and $\mathrm{Mo} \mathrm{JH}$ : Intralymphatic treatment of flagellin-ovalbumin mixture reduced allergic inflammation in murine model of allergic rhinitis. Allergy 71: 629-639, 2016.

105. Chenuet P, Fauconnier L, Madouri F, Marchiol T, Rouxel N, Ledru A, Mauny P, Lory R, Uttenhove C, van Snick J, et al: Neutralization of either IL-17A or IL-17F is sufficient to inhibit house dust mite induced allergic asthma in mice. Clin Sci (Lond) 131: 2533-2548, 2017.

106. Al-Alwan LA, Chang Y, Mogas A, Halayko AJ, Baglole CJ, Martin JG, Rousseau S, Eidelman DH and Hamid Q: Differential roles of CXCL2 and CXCL3 and their receptors in regulating normal and asthmatic airway smooth muscle cell migration. J Immunol 191: 2731-2741, 2013.

107. Dixit N and Simon SI: Chemokines, selectins and intracellular calcium flux: Temporal and spatial cues for leukocyte arrest. Front Immunol 3: 188, 2012.

108. Baos S, Calzada D, Cremades L, Sastre J, Quiralte J, Florido F, Lahoz C and Cárdaba B: Biomarkers associated with disease severity in allergic and nonallergic asthma. Mol Immunol 82: 34-45, 2017

109. Charrad R, Kaabachi W, Rafrafi A, Berraies A, Hamzaoui K and Hamzaoui A: IL-8 gene variants and expression in childhood asthma. Lung 195: 749-757, 2017.

110. Lee MF, Song PP, Hwang GY, Lin SJ and Chen YH: Sensitization to Per a 2 of the American cockroach correlates with more clinical severity among airway allergic patients in Taiwan. Ann Allergy Asthma Immunol 108: 243-248, 2012

111. Yang T, Li Y, Lyu Z, Huang K, Corrigan CJ, Ying S, Wang W and Wang C: Characteristics of proinflammatory cytokines and chemokines in airways of asthmatics: Relationships with disease severity and infiltration of inflammatory cells. Chin Med J (Engl) 130: 2033-2040, 2017.

112. Wang X, Zhang N, Bo M, Holtappels G, Zheng M, Lou H, Wang $\mathrm{H}$, Zhang $\mathrm{L}$ and Bachert $\mathrm{C}$ : Diversity of TH cytokine profiles in patients with chronic rhinosinusitis: A multicenter study in Europe, Asia, and Oceania. J Allergy Clin Immunol 138: $1344-1353,2016$.

113. Tomassen P, Vandeplas G, Van Zele T, Cardell LO, Arebro J, Olze H, Förster-Ruhrmann U, Kowalski ML, OlszewskaZiąber A, Holtappels G, et al: Inflammatory endotypes of chronic rhinosinusitis based on cluster analysis of biomarkers. J Allergy Clin Immunol 137: 1449-1456.e4, 2016.
114. Cui XY, Chen X, Yu CJ, Yang J, Lin ZP, Yin M and Cheng L: Increased expression of toll-like receptors 2 and 4 and related cytokines in persistent allergic rhinitis. Otolaryngol Head Neck Surg 152: 233-238, 2015.

115. Pelikan Z: Cytokines in tears during the secondary keratoconjunctival responses induced by allergic reaction in the nasal mucosa. Ophthalmic Res 52: 32-42, 2014.

116. Pelikan Z: Cytokine profiles in tears accompanying the secondary conjunctival responses induced by nasal allergy. Curr Eye Res 39: 120-132, 2014

117. Kim JA, Cho JH, Park IH, Shin JM, Lee SA and Lee HM: Diese exhaust particles upregulate interleukins IL-6 and IL-8 in nasal fibroblasts. PLoS One 11: e0157058, 2016.

118. Ozturk AB, Bayraktar R, Gogebakan B, Mumbuc S and Bayram H: Comparison of inflammatory cytokine release from nasal epithelial cells of non-atopic non-rhinitic, allergic rhinitic and polyp subjects and effects of diesel exhaust particles in vitro. Allergol Immunopathol (Madr) 45: 473-481, 2017.

119. Hastie AT, Steele C, Dunaway CW, Moore WC, Rector BM, Ampleford E, Li H, Denlinger LC, Jarjour N, Meyers DA, et al; NHLBI Severe Asthma Research Program (SARP): Complex association patterns for inflammatory mediators in induced sputum from subjects with asthma. Clin Exp Allergy 48: 787-797, 2018.

120. Miyajima S, Shigehara K, Kamekura R, Takaki H, Yabe H, Ikegami I, Asai Y, Nishikiori H, Chiba H, Uno E, et al: Activated circulating $\mathrm{T}$ follicular helper cells and skewing of $\mathrm{T}$ follicular helper 2 cells are down-regulated by treatment including an inhaled corticosteroid in patients with allergic asthma. Allergol Int 69: 66-77, 2020.

121. Fujita K, Kobayashi M, Brutkiewicz RR, Hanafusa T, Herndon DN and Suzuki F: Role for IL-4 nonproducing NKT cells in CC-chemokine ligand 2-induced $\mathrm{Th} 2$ cell generation. Immunol Cell Biol 84: 44-50, 2006.

122. Bilenki L, Yang J, Fan Y, Wang S and Yang X: Natural killer T cells contribute to airway inflammation induced eosinophilic by ragweed through enhanced IL-4 and eotaxin production. Eur J Immunol 34: 345-354, 2004.

123. Hong GU, Kim NG, Kim TJ and Ro JY: CD1d expressed in mast cell surface enhances IgE production in B cells by up-regulating CD40L expression and mediator release in allergic asthma in mice. Cell Signal 26: 1105-1117, 2014.

124. Karisola P, Lehto M, Kinaret P, Ahonen N, Haapakoski R, Anthoni M, Taniguchi M, Wolff $\mathrm{H}$, Puustinen A and Alenius $\mathrm{H}$ : Invariant natural killer $\mathrm{T}$ cells play a role in chemotaxis, complement activation and mucus production in a mouse model of airway hyperreactivity and inflammation. PLoS One 10: e0129446, 2015.

125. Woo YD, Koh J, Kang HR, Kim HY and Chung DH: The invariant natural killer T cell-mediated chemokine X-C motif chemokine ligand $1-\mathrm{X}-\mathrm{C}$ motif chemokine receptor 1 axis promotes allergic airway hyperresponsiveness by recruiting CD103 ${ }^{+}$dendritic cells. J Allergy Clin Immunol 142: 1781-1792. e12, 2018.

This work is licensed under a Creative Commons Attribution-NonCommercial-NoDerivatives 4.0 International (CC BY-NC-ND 4.0) License. 